\title{
ZARZĄD KOMISARYCZNY W PRAWIE BANKOWYM
}

Treść: - 1. Ustanowienie zarządu komisarycznego. - 2. Zadania zarządu komisarycznego. - 3. Uprawnienia i sposób działania zarządu komisarycznego. 4. Ustanie bytu zarządu komisarycznego. - 5. Studium przypadków.

\section{Wstęp}

Każdy bank jest instytucją zaufania publicznego ${ }^{1}$. W związku z tym jest niezwykle istotne, aby klienci powierzając bankowi pieniądze oraz zaciągając zobowiązania, posiadali gwarancje profesjonalizmu i bezpieczeństwa. Chodzi tu o zapewnienie takich warunków prowadzenia działalności bankowej, w których klienci będą mieć pewność, że są obsługiwani fachowo, a ich dane osobowe oraz pieniądze są chronione. Z perspektywy bezpieczeństwa środków finansowych ważne jest, aby system bankowy wyposażony był w sprawnie działający nadzór. To on trzyma pieczę nad poprawnością działania mechanizmu bankowego. On kontroluje podejmowane czynności. On wreszcie - gdy bank ma jakieś kłopoty - prowadzi postępowanie uzdrawiające. Stan finansowy banku decyduje o bezpieczeństwie finansowym klientów. I to nie tylko klientów konkretnego banku. Ewentualne bankructwo może bowiem odbić się na całym sektorze bankowym. W tych okolicznościach nadzór musi być wyposażony w narzędzia pozwalające mu skutecznie oddziaływać na banki i w razie konieczności efektywnie wkraczać w ich działalność ${ }^{2}$. Jednym $\mathrm{z}$ takich narzędzi jest ustanowienie $\mathrm{w}$ banku

${ }^{1}$ R. W. KASZUBSKI, Funkcjonalne źródła prawa bankowego publicznego, Kraków 2006, s. 113.

2 Tamże, s. 267. 
zarządu komisarycznego. W ogólnym ujęciu polega ono na przejęciu zarządzania bankiem poprzez wprowadzenie do niego - w miejsce statutowych organów - osób, które o ile to możliwe przywrócą stan banku sprzed kryzysu. Tym samym działalność zarządu komisarycznego polega na odwróceniu niebezpieczeństwa grożącego bankowi i jego klientom. Ustanowienie zarządu komisarycznego w miejsce organów banku oznacza, że organy te dopuściły do zaistnienia sytuacji kryzysowej i samodzielnie nie umiały jej zażegnać, a zatem konieczna jest interwencja z zewnątrz - podjęcie zarządzania przez ekspertów.

\section{Ustanowienie zarządu komisarycznego}

Ustanowienie zarządu komisarycznego przebiega w kliku etapach. Najpierw muszą zaistnieć stosowne przesłanki. Następnie ich istnienie musi zostać stwierdzone, ażeby w końcu uformować zarząd komisaryczny i wprowadzić go do banku. W związku z tym słuszne wydaje się poświęcenie uwagi dwóm fundamentalnym aspektom ustanowienia zarządu komisarycznego, to jest przesłankom ustanowienia i sposobowi ustanowienia.

W art. 145 ust. 1 Pr. Bank. ${ }^{3}$ wskazano, iż ustanowienie zarządu komisarycznego stanowi fakultatywne uprawnienie Komisji Nadzoru Finansowego (dalej KNF), w przypadku gdy zarząd banku nie przekaże programu postępowania naprawczego zgodnie z art. 142 ust. 1, albo gdy realizacja tego programu okaże się nieskuteczna. Należy przez to rozumieć, że dla skutecznego ustanowienia zarządu komisarycznego konieczne jest zaistnienie jednej z sytuacji opisanych w art. 145 ust. 1 oraz uznanie przez KNF zarządzania komisarycznego za stosowne. Istnieją zatem trzy warunki ustanowienia zarządu komisarycznego (brak programu postępowania naprawczego, nieskuteczna jego realizacja i uznanie KNF-u) z czego dwa pierwsze występują alternatywnie $\mathrm{w}$ stosunku do siebie, ale zawsze muszą być spełnione łącznie z warunkiem trzecim.

W tym miejscu warto zwrócić uwagę, że wymienione warunki mają charakter bezpośredni, to znaczy stwierdzenie ich spełnienia decydu-

${ }^{3}$ Ustawa prawo bankowe, Dz.U.02.72.665. 
je o legalności utworzenia zarządu komisarycznego. Można jednak wskazać również warunki pośrednie, których wprawdzie nie bada się analizując kwestię zarządu komisarycznego, ale które leżą u podstaw dwóch alternatywnych warunków bezpośrednich. Warunki bezpośrednie posługują się bowiem pojęciem programu naprawczego i zakładają, że jego stworzenie stało się w banku konieczne. W związku z tym należy się domyślać, iż musiała wystąpić jedna z przesłanek utworzenia programu naprawczego. Przesłanka ta będzie pośrednio również przesłanką powołania zarządu komisarycznego, bowiem bez jej zaistnienia w ogóle nie musiałby być przedstawiany program postępowania naprawczego.

Wobec powyższego wyróżniamy trzy pośrednie przesłanki utworzenia zarządu komisarycznego sformułowane w artykule 142 ust. 1 Pr. Bank $^{4}$. Ogólnie sprowadzają się one do powstania stanu zagrożenia banku, który może polegać na zaistnieniu straty bilansowej, może ograniczyć się jedynie do groźby powstania takiej straty i wreszcie może mieć postać niebezpieczeństwa niewypłacalności banku lub utraty płynności. W tym miejscu konieczne jest jednak poczynienie pewnych wyjaśnień. W przypadku przesłanki pierwszej przez powstanie straty bilansowej należy rozumieć sytuację, w której w bilansie banku - sporządzonym za dany rok obrotowy - odnotowano nadwyżkę wydatków banku nad jego dochodami. Nie ma przy tym znaczenia, czy nadwyżka ta ma charakter minimalny, czy też występuje w stopniu znaczącym. Każda nadwyżka wydatków nad dochodami uzasadnia wszczęcie postępowania sanacyjnego, a zatem przedłożenia KNF programu naprawczego ${ }^{5}$. W stosunku do dalszych przesłanek dyskusyjne jest odnalezienie momentu, w którym można odnotować ich zaistnienie. Stwierdzenie bowiem zagrożenia stratą bilansową, niebezpieczeństwem niewypłacalności lub utraty płynności ma charakter dyskrecjonalny. W tych okolicznościach należy przyjąć, że przesłanki te zostają spełnione wówczas, gdy tylko utrzymanie status quo funkcjonowania

\footnotetext{
${ }^{4}$ Ustawa prawo bankowe, Dz.U.02.72.665.

5 F. Zoll (red.), Prawo bankowe. Komentarz, tom II, Kraków 2005, s. 566.
} 
banku stwarza prawdopodobieństwo powstania straty lub odpowiednio niewypłacalności bądź utraty płynności.

Podsumowując, w razie powstania straty bilansowej, groźby jej nastąpienia albo powstania niebezpieczeństwa niewypłacalności lub utraty płynności zarząd banku musi przedstawić KNF program postępowania naprawczego. Jeśli tego nie uczyni albo też realizacja programu nie przyniesie oczekiwanych skutków, KNF może ustanowić w banku zarząd komisaryczny. W tym celu KNF podejmuje stosowną decyzję. Decyzję tę może podjąć w ramach procedury opisanej w art. 145 Pr. Bank. ${ }^{6}$, która w niniejszych rozważaniach będzie traktowana jako podstawowa. Może też - w szczególnych przypadkach - uczynić to w trybie art. 158 ust. 1 lub 2 Pr. Bank. ${ }^{7}$ tzn. w drodze decyzji o zawieszeniu działalności banku. Wówczas zarząd komisaryczny ustanawiany jest celem zapewnienia przestrzegania przepisów prawa i postanowień decyzji o zawieszeniu. W stosunku do tego szczególnego trybu utworzenia zarządu komisarycznego zwykle stosuje się odpowiednio unormowania przewidziane $\mathrm{w}$ procedurze podstawowej. W związku z tym dalej zostanie omówiona jedynie procedura podstawowa. Tam zaś, gdzie procedura szczególna przejawia odrębności, będzie to zaznaczone.

Zarząd komisaryczny zostaje ustanowiony na mocy decyzji KNF. Decyzja ta ma charakter decyzji administracyjnej i powinna przede wszystkim zawierać: ustanowienie zarządu komisarycznego (wraz z datą ustanowienia), powołanie konkretnych zarządców przez wymienienie ich imion i nazwisk, zadania zarządu komisarycznego oraz wysokość wynagrodzenia zarządców. Może nadto zawierać inne elementy - takie jak np. sposób spełniania obowiązku informacyjnego ${ }^{8}$.

Na mocy art. 145 ust. 4 Pr. Bank. ${ }^{9}$ decyzja KNF, jako decyzja administracyjna, podlega zaskarżeniu. Rada nadzorcza sanowanego banku może, w terminie 7 dni od doręczenia decyzji, wnieść na nią skargę

\footnotetext{
${ }^{6}$ Ustawa prawo bankowe, Dz.U.02.72.665.

7 Tamże.

8 M. BĄczyK, Zarys prawa bankowego, część I, Toruń 2000, s. 176.

9 Ustawa prawo bankowe, Dz.U.02.72.665.
} 
do Naczelnego Sądu Administracyjnego. W tym miejscu należy zaznaczyć, że z chwilą wydania decyzji organy banku zostają zawieszone w swojej działalności. Jednakże mimo tego zawieszenia rada nadzorcza pozostaje kompetentna do skarżenia decyzji o ustanowieniu zarządu komisarycznego. Takie uregulowanie wydaje się pozostawać w zgodzie ze względami słuszności, trudno byłoby bowiem oczekiwać, iż sam zarząd komisaryczny - jako jedyny aktywny organ banku - domagał się będzie kontroli swego ustanowienia. Niedotrzymanie siedmiodniowego terminu do wniesienia skargi pociąga za sobą skutek odrzucenia wspomnianego środka zaskarżenia. Wniesienia skargi dokonuje się tylko i wyłącznie za pośrednictwem KNF, która to Komisja jest obowiązana - w terminie 30 dni od otrzymania skargi - przekazać ją do sądu wraz ze swoją odpowiedzią i aktami sprawy. Sąd administracyjny rozpatrując skargę bada jedynie to, czy jej wydanie było zgodne z prawem. Nie rozważa natomiast celowości ustanowienia zarządu komisarycznego. Kontrola odbywa się więc jedynie pod kątem legalności wydanej decyzji ${ }^{10}$. Skarga na omawianą decyzję nie ma charakteru suspensywnego, czyli jej wniesienie nie powoduje wstrzymania wykonania decyzji. Wobec tego mimo zaskarżenia zarząd komisaryczny pełni swoje obowiązki w ramach postępowania naprawczego. Zgodnie $\mathrm{z}$ art. $61 \S 3$ Prawa o postępowaniu przed sądami administracyjnymi ${ }^{11}$, zaskarżenie decyzji nie wstrzymuje jej wykonania, co nie oznacza, że Naczelny Sąd Administracyjny nie może postanowić o wstrzymaniu wykonania decyzji na czas rozpatrzenia sprawy. Zwłaszcza jeśliby istniało ryzyko wyrządzenia skarżoną decyzją krzywdy ${ }^{12}$. Jeśli Naczelny Sąd Administracyjny uzna, że decyzja o ustanowieniu zarządu komisarycznego została wydana z naruszeniem prawa, wówczas KNF ponosi odpowiedzialność odszkodowawczą za wyrządzone decyzją

${ }^{10}$ A. Skoczylas, Zaskarżanie do sądu administracyjnego decyzji o ustanowieniu zarzadu komisarycznego banku - wybrane zagadnienia, Prawo Bankowe, 2001 nr 1, s. 93.

${ }^{11}$ Ustawa z dnia 30 sierpnia 2002 r. Prawo o postępowaniu przed sądami administracyjnymi, Dz.U.02.153.1270.

${ }^{12}$ A. Skoczylas, Wstrzymanie wykonania decyzji Komisji Nadzoru Bankowego, Prawo Bankowe, $2001 \mathrm{nr}$ 4, s. 61-62. 
szkody $^{13}$. Należy zaznaczyć, że skarga na decyzję jest jedynym środkiem, jaki przeciwko decyzji można przedsięwziąć. Niedopuszczalne jest bowiem zwrócenie się do KNF o ponowne rozpatrzenie sprawy ${ }^{14}$. Istotnym jest wreszcie, że przepisu o zaskarżalności decyzji KNF nie stosuje się w przypadku ustanowienia zarządu komisarycznego w trybie art. 158 ust. 51 lub 2 Pr. Bank ${ }^{15}$.

Decyzja o ustanowieniu zarządu komisarycznego wymaga odnotowania w stosownym rejestrze. Rejestrem tym jest Krajowy Rejestr Sądowy. Inaczej jest jednak w przypadku banków państwowych, banki te nie podlegają bowiem wpisowi do rejestru przedsiębiorców. Nabywają one podmiotowość prawną na mocy rozporządzenia Rady Ministrów. $\mathrm{W}$ związku z tym ustanowienie w nich zarządu komisarycznego nie podlega ujawnieniu w żadnym rejestrze. Wpis do rejestru jest obowiązkowy, ale nie wywołuje żadnych skutków w obszarze działalności zarządu komisarycznego, który legitymację do działania czerpie z decyzji o swym ustanowieniu. Tak więc wpis do rejestru ma charakter deklaratoryjny. Obowiązek dokonania zgłoszenia ciąży - jak się wydaje - na samym zarządzie komisarycznym, jako że on właśnie przejmuje kompetencje organów banku, a przejmując ich prawa, przejmuje także obowiązki ${ }^{16}$.

\section{Zadania zarządu komisarycznego}

Zarząd komisaryczny jako środek postępowania naprawczego ma do zrealizowania określone zadania, które sprowadzają się do wspólnego mianownika, którym jest uzdrowienie banku. Artykuł $145 \mathrm{Pr}$. Bank. ${ }^{17}$ regulujący działalność zarządu komisarycznego dzieli zadania zarządu komisarycznego niejako na dwie grupy. Pierwszą grupą

${ }^{13}$ A. SkoczYlas, Środki ochrony banku w postępowaniu przed Komisją Nadzoru Bankowego (wybrane zagadnienia), Prawo Bankowe, 2002 nr 2, s. 61

${ }^{14}$ F. Zoll (red.), Prawo bankowe. Komentarz, tom II, Kraków 2005, s. 605.

${ }^{15}$ Ustawa prawo bankowe, Dz.U.02.72.665.

${ }^{16}$ K. KoHUTEK, Sanacja banku $w$ bankowych procedurach naprawczych $i$ w postępowaniu upadłościowym, Kraków 2005, s. 293; Inaczej: Z. Ofiarski, Prawo bankowe, Kraków 2008, s. 314.

${ }^{17}$ Ustawa prawo bankowe, Dz.U.02.72.665. 
są zadania określone wprost $\mathrm{w}$ ustawie. Należą do nich opracowanie i uzgodnienie z KNF programu postępowania naprawczego, kierowanie realizacją programu postępowania naprawczego oraz informowanie KNF i rady nadzorczej o wynikach realizacji programu (nie rzadziej niż co trzy miesiące). Obok zadań wymienionych w art. 145 Pr. Bank. ${ }^{18}$, do grupy zadań bezpośrednio wyrażonych w ustawie należy jeszcze zaliczyć zadanie ustanowione przez art. 158 Pr. Bank. ${ }^{19}$. Mianowicie, chodzi tu o obowiązek niezwłocznego zawiadomienia KNF, jeśli bilans banku wykaże stan, z którego wynika, że aktywa banku nie wystarczają na zaspokojenie jego zobowiązań.

W tym miejscu warto zaznaczyć, iż kwestia zadań zarządu komisarycznego rysuje się odmiennie w przypadku ustanowienia zarządu komisarycznego w trybie art. 158 ust. 51 lub 2 Pr. Bank. ${ }^{20}$. Przepis ten przewiduje, że KNF może utworzyć zarząd komisaryczny podejmując decyzję o zawieszeniu działalności banku. W tym szczególnym przypadku oczywiste jest, że rola zarządu komisarycznego nie będzie sprowadzała się do realizacji programu naprawczego. Celem utworzenia zarządu komisarycznego będzie raczej zapewnienie przestrzegania wszystkich aspektów decyzji o zawieszeniu działalności banku. Zadania zarządu komisarycznego będą więc polegały na realizacji owego celu. Zarząd komisaryczny będzie co do zasady powolywany nie dla przeprowadzenia naprawy sytuacji banku, lecz w celu niedopuszczenia do pogorszenia jego położenia i przygotowania banku do przejęcia przez inny bank. Niecelowe bytoby bowiem powolywanie zarzadu komisarycznego, którego zadanie polegatoby na przygotowaniu banku do upadtości $i^{21}$.

Wracając do analizy zarządu komisarycznego w jego podstawowej formie, drugą grupą zadań stojących przed zarządem komisarycznym są - w myśl art. 145 ust. 3 Pr. Bank. ${ }^{22}$ - zadania określone w decyzji

${ }^{18}$ Tamże.

${ }^{19}$ Tamże.

${ }^{20}$ Ustawa prawo bankowe, Dz.U.02.72.665.

${ }^{21}$ R. W. KaszuBsKi, Funkcjonalne źródła prawa bankowego publicznego, Kraków 2006, s. 282.

${ }^{22}$ Tamże. 
o ustanowieniu zarządu komisarycznego. Katalog owych zadań jest otwarty i od uznania KNF zależy jakie dodatkowe zadania postawi ona przed zarządem komisarycznym. Przykładowo, wśród zadań tych mogą się znaleźć: ustalenie sytuacji ekonomiczno-finansowej banku; windykacja należności banku; pozyskiwanie nowych kapitałów w celu uzupełnienia funduszy własnych banku; porządkowanie struktur organizacyjnych i zarządzania bankiem; regulacje kadrowe; a także redukcja sieci placówek ${ }^{23}$. W literaturze podnosi się jednak, że niezależnie od uznaniowości określenia przez KNF omawianych zadań, ich wyznaczenie możliwe jest tylko i wyłącznie w decyzji o ustanowieniu zarządu komisarycznego. KNF nie może więc uczynić tego w żadnym innym akcie ${ }^{24}$.

Obok zadań wyrażonych w ustawie i decyzji o utworzeniu zarządu komisarycznego, na omawianym organie - jak wskazuje Konrad Kohutek - spoczywają zadania, które teoretycznie nigdzie nie zostały wymienione, ale w sposób oczywisty wynikają z art. 145 ust. 1 Pr. Bank. Przepis ten stanowi, iż ustanowienie zarzadu komisarycznego nie wpływa na organizację i sposób działania banku jako osoby prawnej. Dla zapewnienia bowiem takiej organizacji i takiego sposobu działania konieczne jest wykonywanie obowiązków ciążących na organach banku w myśl Kodeksu spółek handlowych, ustawy Prawo spółdzielcze $^{25}$ czy też ustawy Prawo bankowe ${ }^{26}$. I tak, na przykład, na zarządzie komisarycznym spoczywa obowiązek dokonywania zgłoszenia zmiany statutu do sądu rejestrowego; prowadzenie rejestru członków banku spółdzielczego; czy chociażby samo zgłoszenie ustanowienia w danym banku zarządu komisarycznego ${ }^{27}$. Wszystkie wymienione

${ }^{23}$ T. Hoffmann, Zarząd komisaryczny na tle polskiej praktyki bankowej, Bank i kredyt, 1994 nr 9, s. 7-10; K. KoHUTEK, Sanacja banku w bankowych procedurach naprawczych $i$ w postepowaniu upadłościowym, Kraków 2005, s. 319.

${ }^{24}$ E. Fojcik-Mastalska (red.), Prawo bankowe komentarz, Warszawa 2005, s. 697.

${ }^{25} \mathrm{~K}$. KoHUTeK, Sanacja banku $w$ bankowych procedurach naprawczych $i$ w postępowaniu upadtościowym, Kraków 2005, s. 320.

${ }^{26}$ Kodeks spółek handlowych, Dz.U.00.94.1037; Ustawa prawo spółdzielcze, Dz.U.03.188.1848; Ustawa prawo bankowe, Dz.U.02.72.665.

${ }^{27}$ F. Zoll (red.), Prawo bankowe. Komentarz, tom II, Kraków 2005, s. 607. 
zadania zarządu komisarycznego, będące celami same w sobie, służą oczywiście osiągnięciu celu najwyższego, jakim jest wyprowadzenie banku z sytuacji kryzysowej.

\section{Uprawnienia i sposób działania zarządu komisarycznego}

Ponieważ sanacja banku, jako instytucji zaufania publicznego, jest szczególnie ważnym przedsięwzięciem, zarząd komisaryczny został wyposażony w rozległe środki służące osiągnięciu zamierzonych celów. Środki te są rozmaitymi uprawnieniami, z których głównym i zdaje się - najbardziej doniosłym jest prawo podejmowania uchwat $i$ decyzji we wszystkich sprawach zastrzeżonych $w$ ustawie $i$ statucie do właściwości władz i organów banku ${ }^{28}$. Z chwilą ustanowienia zarządu komisarycznego bowiem, wszystkie dotychczasowe organy banku zostają zawieszone, a w ich miejsce wchodzi zarząd komisaryczny, w którego rękach scalona jest moc wszystkich tych organów. Dlatego też zarząd komisaryczny często nazywany jest szczególnym organem banku ${ }^{29}$. Jako organ pełni on zarazem funkcję uchwałodawczą, zarządczą i nadzorczą. Nosi więc znamiona swoistej uniwersalności. Jak wskazuje Remigiusz Witold Kaszubski, to że omawiany organ może podejmować decyzje we wszelkich sprawach, uwypukla jego specyfikę. Bowiem za sprawą owego szczególnego uprawnienia, zarząd komisaryczny może na przykład zmienić statut, udzielić sobie absolutorium lub też dokonać zmian $w$ składzie rady nadzorczej ${ }^{30}$.

Omawiając kwestię uprawnień zarządu komisarycznego warto również wspomnieć o regulacji zawartej w art. 145 ust. 2a Pr.Bank. ${ }^{31}$. Przepis ten przekazuje do kompetencji zarządu komisarycznego możność zamknięcia ksiąg rachunkowych banku i sporządzenia sprawoz-

${ }^{28}$ Ustawa prawo bankowe, Dz.U.02.72.665, art. 145 ust. 2.

${ }^{29}$ Uchwała Sądu Najwyższego III CZP 61/98, OSNC 1999/12/201, uzasadnienie, pkt. 3; B. Smyкla, Postępowanie uzdrawiajace, zarząd komisaryczny, likwidacja, przejęcie i upadtość banku. Instrumenty regulacji sektora bankowego $w$ Prawie bankowym, Bank i kredyt, 1994 nr 1-2, s. 14.

${ }^{30}$ R. W. KaszubsKi, Administracyjna ingerencja $w$ działalność banków (cz. I), Glosa, 1996 nr 6, s. 9.

${ }^{31}$ Ustawa prawo bankowe, Dz.U.02.72.665. 
dania finansowego na dzień wyznaczony przez KNF, a także możność podjęcia uchwały o pokryciu straty za okres kończący się w tym właśnie dniu, oraz straty za lata ubiegłe. Uprawnienie to umożliwia zarządowi komisarycznemu sprawne rozpoczęcie procesu restrukturyzacji banku $u^{32}$.

Ustanowienie zarządu komisarycznego w banku dokonuje się w dniu powzięcia odpowiedniej decyzji przez KNF, lub też w innym dniu, wskazanym w owej decyzji. Owo ustanowienie wywiera w banku następujące skutki. Przede wszystkim rada nadzorcza zostaje zawieszona. Od tej chwili władna jest ona jedynie wnieść skargę do sądu administracyjnego na decyzję o utworzeniu zarządu komisarycznego. Przy tym, zostają odwołani członkowie zarządu banku, wygasają ustanowione prokury i pełnomocnictwa oraz zawieszone zostają kompetencje innych organów banku. Członkowie władz banku pozbawieni zostają odpraw pieniężnych i wynagrodzeń za okres po rozwiązaniu stosunku pracy ${ }^{33}$. Prawo podejmowania uchwał i decyzji zastrzeżonych do właściwości władz i organów banku przechodzi na zarząd komisaryczny. Natomiast sama organizacja i sposób działania banku jako osoby prawnej, pozostają bez zmian.

W tym miejscu warto zaznaczyć, że w przypadku wprowadzania zarządu komisarycznego w banku hipotecznym, nie zachodzą żadne zmiany w funkcjonowaniu instytucji powiernika. To znaczy, że nie zostaje on odwołany. Wynika to poniekąd z art. 28 ustawy o listach zastawnych i bankach hipotecznych ${ }^{34}$, który to artykuł w sposób enumeratywny wylicza przypadki, kiedy możliwe jest odwołanie powiernika. Powołanie zarządu komisarycznego wśród tych przypadków nie figuruje. Ponadto, art. 145 ust. 1 zd. 2 Pr. Bank. ${ }^{35}$ stanowi, że powołanie zarządu komisarycznego nie wpływa na organizację i sposób działania

${ }^{32}$ Druk sejmowy (Sejmu IV kadencji) nr 2116, s. 55,

http://orka.sejm.gov.pl/Druki4ka.nsf/(\$vAllByUnid)/2DF18525C82ED9AAC1256DC8003EE348/\$file/2116.pdf

${ }^{33}$ Ustawa prawo bankowe, Dz.U.02.72.665, art. 169.

${ }^{34}$ Ustawa o listach zastawnych i bankach hipotecznych, Dz.U.03.99.919.

${ }^{35}$ Ustawa prawo bankowe, Dz.U.02.72.665. 
banku. A działalność powiernika w banku hipotecznym stanowi (...) zasadniczy element struktury organizacyjnej tego rodzaju bank $u^{36}$.

$\mathrm{Na}$ szczególną uwagę zasługuje kwestia sposobu podejmowania decyzji przez zarząd komisaryczny. W tym zakresie możliwe byłyby trzy metody decydowania: decydowanie $\mathrm{w}$ trybie przewidzianym dla tego organu, którego kompetencje zostały przejęte (tzw. tryb substytucyjny), decydowanie w trybie właściwym tylko dla zarządu komisarycznego (tzw. tryb autonomiczny) albo decydowanie w trybie właściwym dla statutowego zarządu banku.

Dyskusyjne jest, w którym z tych trybów działać powinien zarząd komisaryczny. Generalnie wydaje się, że odrzucić należy możliwość działania zarządu komisarycznego w trybie autonomicznym, jako że wymagałoby to jakichś wyrażonych wprost podstaw prawnych. Tymczasem brak jest przepisów ustanawiających taki tryb działania dla zarządu komisarycznego. Pozostają więc dwie możliwości - działanie $\mathrm{w}$ trybie substytucyjnym i działanie w trybie właściwym dla statutowego zarządu. Mirosław Bączyk uważa, że właściwym dla zarząadu komisarycznego trybem działania jest tryb substytucyjny ${ }^{37}$. To samo stanowisko zajęli sędziowie Sądu Najwyższego w uchwale z dnia 22 lipca 1994 roku $^{38}$. Tymczasem Konrad Kohutek zdecydowanie opowiada się za uznaniem za właściwy dla zarządu komisarycznego, trybu działania statutowego zarządu banku ${ }^{39}$. Ten punkt widzenia znajduje poparcie w uchwale Sądu Najwyższego (w składzie siedmiu sędziów) z dnia 30 kwietnia 1999 roku $^{40}$. Wydaje się, że postulowane tu działanie zarządu komisarycznego $\mathrm{w}$ trybie statutowego zarządu banku jest najprostszym i najbardziej praktycznym rozwiązaniem. Za jego sprawą zarząd komisaryczny działa zawsze według jednego i tego samego klucza, niezależnie od rozstrzyganej sprawy. Musi to stanowić istotne

\footnotetext{
${ }^{36}$ K. KoHUteK, Sanacja banku $w$ bankowych procedurach naprawczych $i$ w postępowaniu upadtościowym, Kraków 2005, s. 299.

${ }^{37}$ M. BĄCZYK, Zarys prawa bankowego, część I, Toruń 2000, s. 185.

${ }^{38}$ Uchwała Sądu Najwyższego III CZP 92/94, OSNC 1995/1/8.

${ }^{39} \mathrm{~K}$. KoHUTeK, Sanacja banku $w$ bankowych procedurach naprawczych $i$ w postępowaniu upadłościowym, Kraków 2005, s. 328.

${ }^{40}$ Uchwała Sądu Najwyższego III CZP 61/98, OSNC 1999/12/201.
} 
uproszczenie i usprawnienie działań zarządu. Poza tym, powyższe rozwiązanie pozwala na uniknięcie problemów, które nastręczałoby stosowanie trybu substycyjnego. Mianowicie - w przypadku czynności należących do kompetencji walnego zgromadzenia - „siła” głosu na zgromadzeniu zależy od ilości posiadanych akcji. Głosuje się bowiem, mówiąc potocznie, według kapitału, a nie według głów. Tymczasem nie ulega wątpliwości, że zarządcy komisaryczni nie posiadają akcji banku i nie reprezentują żadnej części kapitału zakładowego. Wobec tego trudno odpowiedzieć na pytanie, w jaki sposób zarząd komisaryczny miałby działać w trybie walnego zgromadzenia, żeby trybowi temu nie uchybić. Wreszcie, warto przytoczyć spostrzeżenie Konrada Kohutka, iż wykładnia językowa obowiązujących przepisów zdaje się sugerować, że zarząd komisaryczny powinien działać w trybie zarządu statutowego. W nazwie organu figuruje bowiem określenie „zarząd”, co może być znakiem tego, że ustawodawca na kształt zarządu właśnie chciał ten szczególny organ ukształtować ${ }^{41}$.

Jak wiadomo, w myśl polskiego prawa banki komercyjne mogą mieć formę bądź spółki akcyjnej, bądź spółdzielni. Wobec tego dalsza analiza trybu działania zarządu komisarycznego musi być przeprowadzona w oparciu o podział banków ze względu na formę prawną. W pierwszej kolejności omówione zostaną banki spółdzielcze. Zarząd komisaryczny powinien w swoich działaniach uwzględniać przepisy prawa spółdzielczego ${ }^{42}$, a zatem między zasady, iż: zarząd komisaryczny powinien kierować działalnością banku oraz reprezentować go na zewnątrz (art. $48 \S 1$ ), zarządcy komisaryczni powinni protokołować podejmowane decyzje (art. $41 \S 3$ ), oświadczenia woli za bank powinni składać dwaj członkowie zarządu komisarycznego lub jeden członek zarządu komisarycznego i pełnomocnik (art. 54), w razie podjęcia decyzji o wykluczeniu lub wykreśleniu członka banku spółdzielczego, zarząd komisaryczny powinien uzasadnić swoją decyzję, pisemnie zawiadomić o niej zainteresowanego oraz wysłuchać go (art. 24),

${ }^{41} \mathrm{~K}$. KoHUTEK, Sanacja banku $w$ bankowych procedurach naprawczych $i$ w postępowaniu upadłościowym, Kraków 2005, s. 329.

${ }^{42}$ Ustawa prawo spółdzielcze, Dz.U.03.188.1848. 
członkowie spółdzielni mogą odwoływać się od uchwał zarządu komisarycznego na drodze sądowej (art. 32 §3), oraz zasadę, iż członek zarządu komisarycznego odpowiada wobec banku za szkodę wyrządzoną działaniem lub zaniechaniem sprzecznym z prawem lub postanowieniami statutu banku, chyba że nie ponosi winy (art. 58).

Jeśli chodzi o banki akcyjne, to przyjmując, iż właściwy dla zarządu komisarycznego jest tryb działania statutowego zarządu, należy uznać, że zarząd komisaryczny w banku akcyjnym powinien funkcjonować między innymi w oparciu o następujące zasady, wynika-

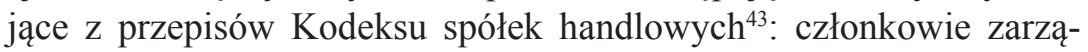
du komisarycznego powinni wspólnie dążyć do realizacji programu naprawczego (art. $371 \S 1$ ); uchwały zarządu, o ile statut banku nie stanowi inaczej, zapadać powinny bezwzględną większością głosów (art. 371 §2); uchwały zarządu komisarycznego mogą być powzięte tylko wówczas, gdy wszyscy członkowie zarządu komisarycznego zostali prawidłowo zawiadomieni o posiedzeniu (art. 371 §3); uchwały zarządu komisarycznego powinny być protokołowane, przy czym protokoły powinny zawierać porządek obrad, nazwiska i imiona obecnych członków zarządu komisarycznego, liczbę głosów oddanych na poszczególne uchwały, zdania odrębne i podpisy obecnych członków zarządu komisarycznego (art. 376); zarząd komisaryczny może sam uchwalić swój regulamin (art. 371 §6); powołanie prokurenta wymaga zgody wszystkich członków zarządu komisarycznego (art. 371 §4); odwołać prokurę może każdy członek zarządu komisarycznego (art. $371 \S 5$ ); zarządca komisaryczny ma prawo do reprezentowania banku we wszystkich czynnościach sądowych i pozasądowych (art. $372 \S 1$ ); jeżeli statut nie stanowi inaczej do składania oświadczeń w imieniu spółki będącej bankiem wymagane jest współdziałanie dwóch członków zarządu komisarycznego albo jednego członka zarządu komisarycznego łącznie z prokurentem (art. 373 §1); i wreszcie, oświadczenia składane spółce będącej bankiem oraz doręczenia pism spółce będącej bankiem mogą być dokonywane wobec jednego członka zarządu komisarycznego lub prokurenta (art. 373 §2).

\footnotetext{
${ }^{43}$ Kodeks spółek handlowych, Dz.U.00.94.1037.
} 
Wspomniawszy o uchwałach podejmowanych przez zarząd komisaryczny, warto poświęcić odrobinę uwagi kwestii odpowiedzialności za treść uchwał zarządu komisarycznego w bankach będących spółkami akcyjnymi. Nie da się bowiem ukryć, że niezależnie od prowadzonego postępowania sanacyjnego, nie sposób odmówić akcjonariuszom prawa do ochrony ich interesów. Jak napisał Mirosław Bączyk - odjęcie kompetencji organom banku (...) i przejęcie jej przez zarząd komisaryczny nie może pozbawiać właścicieli kapitału akcyjnego niezbędnej ochrony przewidzianej w przepisach normujacych tryb podejmowania uchwat w normalnych warunkach ${ }^{44}$. Wobec powyższego, na straży interesów akcjonariuszy - jak wskazuje Konrad Kohutek ${ }^{45}$ - stoją przepisy zawarte w art. 422 i 425 kodeksu spółek handlowych ${ }^{46}$. Na mocy pierwszego z nich mogą być zaskarżone, a w wyniku tego uchylone przez sąd, uchwały zarządu komisarycznego, które spełniają łącznie dwa warunki: są sprzeczne ze statutem bądź dobrymi obyczajami i godzą w interes spółki lub mają na celu pokrzywdzenie akcjonariusza. Na mocy zaś drugiego z przywołanych artykułów można dochodzić stwierdzenia nieważności uchwały pozostającej w sprzeczności z ustawą. Ponadto Sąd Najwyższy w przywoływanej już uchwale siedmiu sędziów, z 30 kwietnia 1999 roku ${ }^{47}$, uznał za dopuszczalną odpowiedzialność odszkodowawczą członków zarządu komisarycznego w wypadku wyrządzenia przez nich szkody bankowi. Z kolei Ryszard Tupin wskazuje, że niezależnie od tego, akcjonariusze banku mogą pozywać członków zarządu komisarycznego na zasadach ogólnych, czyli na podstawie art. 415 Kodeksu cywilnego ${ }^{48}$. Jak zauważył autor, ponieważ członkowie zarzadu komisarycznego nie działaja $w$ charakterze funkcjonariuszy państwowych, nie ma podstaw do odpowiedzialności cywilnej Skarbu Państwa za ich działania lub zaniechania. Odpowia-

${ }^{44}$ M. BĄCZYK, Zarząd komisaryczny w banku, „Rzeczpospolita”, 1993 nr 217, s. 14.

${ }^{45} \mathrm{~K}$. KoHUTeK, Dopuszczalność zaskarżania uchwał ustanowionego w banku zarzadu komisarycznego na podstawie art. 422 i 425 kodeksu spółek handlowych, Transformacje prawa prywatnego, $2001 \mathrm{nr} 3$, s. 25-36.

${ }^{46}$ Kodeks spółek handlowych, Dz.U.00.94.1037.

${ }^{47}$ Uchwała Sądu Najwyższego III CZP 61/98, OSNC 1999/12/201.

${ }^{48}$ Kodeks cywilny, Dz.U.64.16.93. 
daja oni w tym zakresie samodzielnie za ew. szkodę wyrządzona bankowi lub jego akcjonariuszom ${ }^{49}$. Mimo więc, że ustawa nie przewiduje żadnych sankcji dla zarządców komisarycznych za nierealizowanie swoich zadań, nie pozostają oni bezkarni.

\section{Ustanie bytu zarządu komisarycznego}

W myśl Pr. Bank. ${ }^{50}$ zarząd komisaryczny powoływany jest na czas realizacji programu postępowania naprawczego. Wobec tego, możemy stwierdzić, że w ustawie nie określono dokładnie ${ }^{51}$, na jaki czas ustanawiany ma być zarząd komisaryczny. Według Konrada Kohutka wynika to z tego, że ustawodawca wyszedł z założenia, iż nie da się określić w sposób ścisły, ile czasu pochłonie zarządowi komisarycznemu sanacja zagrożonego banku. Zarząd powinien funkcjonować tak długo, jak jest to niezbędne, przy czym chodzi tu tak o udana realizacje (...) celu [uzdrowienia], jak i nieskuteczność działań zarzadców komisarycznych ${ }^{52}$. Nie wyklucza to jednak ustanowienia terminu zakończenia działania zarząa komisarycznego w decyzji o jego ustanowieniu. $\mathrm{O}$ ile bowiem ustawodawca konstruuje przepisy abstrakcyjnie, o tyle KNF - wydając decyzję - spotyka się z oznaczonymi przypadkami. Może więc próbować ocenić, na podstawie posiadanych informacji, jak długo potrzebne będzie zarządzanie komisaryczne. Oczywiście, niezależnie od tego KNF może ustanowić zarząd komisaryczny na okres nieoznaczony. Jeśli natomiast oznaczy w decyzji czas działania zarządu komisarycznego, nic nie stoi na przeszkodzie, aby okres ten przedłużyła.

Wobec tego, zakończenie działalności zarządu komisarycznego możliwe jest w następujących przypadkach: gdy upłynie termin, określony w decyzji o ustanowieniu zarządu komisarycznego (wówczas w zależności od efektów działania zarządu komisarycznego, albo

\footnotetext{
${ }^{49}$ R. Tupin, Odpowiedzialność cywilna Skarbu Państwa za działania lub zaniechania nadzoru bankowego, Prawo Bankowe, 2000 nr 11, s. 44.

${ }^{50}$ Ustawa prawo bankowe, Dz.U.02.72.665, art. 145 ust. 1.

${ }^{51} \mathrm{~Np}$. w dniach czy miesiącach.

${ }^{52}$ K. KoHUTeK, Sanacja banku $w$ bankowych procedurach naprawczych $i$ w postępowaniu upadtościowym, Kraków 2005, s. 338.
} 
bank wraca do normalnego funkcjonowania, albo dalej jest poddawany działaniom sanacyjnym); gdy KNF wyda decyzję o odwołaniu zarządu komisarycznego, z powodu poprawienia się sytuacji finansowej banku (może to mieć miejsce wówczas, gdy sytuacja ta poprawi się do tego stopnia, iż bank nie będzie stanowił już zagrożenia dla stabilności systemu i ponownie będzie spełniał standardy bezpieczeństwa - tzw. ,pozytywna" przesłanka odwołania zarządu ${ }^{53}$ ); gdy KNF podejmie decyzję o przymusowym przejęciu banku (art. 148 ust. 1 pkt 1 Pr. Bank. ${ }^{54}$ ); gdy zarządzanie bankiem zostanie przejęte przez likwidatora (art. 153 ust. 2 pkt 1 Pr. Bank. ${ }^{55}$ ); oraz gdy ogłoszona zostanie upadłość banku (art. 433 pkt 2 Prawa upadłościowego i naprawczego ${ }^{56}$ ). Należy zaznaczyć, że w przypadku przejęcia banku, generalnie można mówić o sukcesie zarządzania komisarycznego. Przejęcie banku oznacza bowiem, że jego klientom nadal świadczone będą usługi i nie dojdzie do upadłości banku ${ }^{57}$. Z kolei dwa ostatnie przypadki charakteryzuje wspólna cecha, przejawiająca się tym, że podejmowane przez zarząd komisaryczny działania pogłębiły trudności banku lub też okazały się nieskuteczne (tzw. „negatywna” przesłanka odwołania zarządu) ${ }^{58}$. W takich okolicznościach w banku kończy się okres działalności zarządu komisarycznego, a zamiast tego podejmowane są inne działania nadzorcze.

Jeśli chodzi o odwołanie zarządu komisarycznego, to ustawa nie wskazuje wprost, kto jest upoważniony do podjęcia odpowiedniej decyzji. Doktryna ${ }^{59}$ stoi jednak na stanowisku, że uprawnienia w tym za-

${ }^{53}$ Tamże, s. 340.

${ }^{54}$ Ustawa prawo bankowe, Dz.U.02.72.665.

${ }^{55}$ Tamże.

${ }^{56}$ Ustawa prawo upadłościowe i naprawcze, Dz.U.03.60.535.

${ }^{57}$ Wydaje się więc, iż wbrew K. Kohutkowi można pokusić się o stwierdzenie, że przejęcie banku również stanowi pozytywną (nie negatywną) przesłankę odwołania zarządu komisarycznego.

${ }^{58}$ K. KonUteK, Sanacja banku $w$ bankowych procedurach naprawczych $i$ w postępowaniu upadłościowym, Kraków 2005, s. 340.

${ }^{59}$ M. BĄCZYK, Zarys prawa bankowego, część I, Toruń 2000, s. 177; B. SMYKLA, Postępowanie uzdrawiające, zarząd komisaryczny, likwidacja, przejęcie $i$ upadłość banku. Instrumenty regulacji sektora bankowego w Prawie bankowym, Bank i kredyt, $1994 \mathrm{nr} 1-2$, s. 16. 
kresie przysługują KNF. Pogląd taki jest konsekwencją, nazwijmy to, symetrycznego rozumowania. Skoro bowiem KNF ustanawia zarząd komisaryczny, ona powinna być też uprawniona do jego odwołania.

\section{Studium przypadków}

Chcąc spojrzeć na instytucję zarządu komisarycznego z praktycznego punktu widzenia, należy stwierdzić, iż w Polsce, dawno już nie było potrzeby ustanawiania zarządu komisarycznego w bankach. Niewątpliwie świadczy to o nienajgorszej kondycji sektora bankowego. Przypadki ustanowienia zarządu pochodzą z pierwszej połowy minionej dekady. I tak, 7 lutego 2002 roku ówczesna Komisja Nadzoru Bankowego (dalej KNB) wprowadziła zarząd komisaryczny w Banku Społem SA ${ }^{60}$. Przyczyną tej decyzji był brak efektywnych działań ze strony władz banku zmierzajacych do ustabilizowania jego sytuacji oraz brak przedstawienia projektu programu naprawczego. Sprawa ta była nawet podstawą interpelacji poselskiej nr 681 z 2002 roku, w odpowiedzi na którą podsekretarz stanu w Ministerstwie Finansów wyjaśniał merytoryczne i prawne przesłanki zasadności wprowadzenia zarządu komisarycznego w powyższej sytuacji ${ }^{61}$. W październiku 2002 roku KNB zgodziła się (...), aby spótka LOOK Finansowanie Inwestycji, należaca do Mariusza Łukasiewicza, miała prawo do wykonywania ponad 75 proc. głosów na walnym zgromadzeniu akcjonariuszy Banku Społem ${ }^{62}$. 5 lutego 2003 roku KNB uchyliła decyzję o ustanowieniu zarządu komisarycznego w Banku Społem S.A. w Warszawie ${ }^{63}$. Można więc powiedzieć, że w tym przypadku sanacja zakończyła się pomyślnie.

Z kolei decyzją KNB z 21 czerwca 2002 roku został ustanowiony zarząd komisaryczny w Banku Wschodnim SA ${ }^{64}$. Problemy finansowe tego banku spowodowane były, między innymi, działaniami jego władz, polegającymi na nieuzasadnionych zakupach akcji innych spół-

\footnotetext{
${ }^{60} \mathrm{http}: / /$ www.nbp.pl/Home.aspx?f=aktualnosci/Wiadomosci_2002/knb_02b.html

${ }^{61} \mathrm{http}: / /$ orka2.sejm.gov.pl/IZ4.nsf/main/22E8D580

${ }^{62} \mathrm{http}: / /$ new-arch.rp.pl/artykul/405108_Banki.html

${ }^{63} \mathrm{http}: / / w w w . k p w i g . g o v . p l / I m a g e s / \mathrm{knb} 050203$ tcm20-9784.pdf

${ }^{64} \mathrm{https}: / /$ ssl.nbp.pl/Home.aspx?f=aktualnosci/Wiadomosci_2002/knb_210602. html
} 
ek, a także na udzielaniu nieściągalnych kredytów. Straty banku oszacowano na 16 milionów złotych, a prezesowi i wiceprezesowi banku przedstawiono zarzuty niegospodarności ${ }^{65}$. KNB w decyzji o ustanowieniu zarządu komisarycznego zobowiązała organ sanacyjny do podjęcia negocjacji z inwestorem Mariuszem Łukaszewiczem (a więc z tym samym inwestorem, który był związany z sanacją Banku Społem SA). Ostatecznie 23 grudnia 2002 roku Bank Społem SA objął zarząd majątkiem Banku Wschodniego SA, a następnie doszło do przejęcia Banku Wschodniego SA przez Bank Społem SA ${ }^{66}$. W ten sposób powstał Euro Bank SA ${ }^{67}$. Wobec tego sanacja Banku Wschodniego SA zakończyła się przejęciem banku, a zatem sukcesem.

Kolejnym bankiem, który wpadł w kłopoty finansowe i w którym, w 2002 roku, KNB ustanowiła zarząd komisaryczny, był Wschodni Bank Cukrownictwa SA. Ustanowienie zarządu komisarycznego miało miejsce $\mathrm{w}$ drodze decyzji KNB z dnia 25 czerwca 2002 r. $^{68}$ i nastąpiło $\mathrm{w}$ związku z brakiem efektywnych działań naprawczych $w$ restrukturyzowanym banku oraz brakiem efektywnych działań wtadz tego banku zmierzających do dokapitalizowania, co umożliwiłoby przeprowadzenie procesu sanacji. KNB zobowiązała zarząd komisaryczny do podjęcia rozmów z grupą największych polskich banków w celu dokapitalizowania. Banki osiągnęły porozumienie i w 2005 roku podstawowe cele programu naprawczego zostały osiagnięte. (...) We wrześniu 2005 r. pomiędzy dwunastoma Bankami-Akcjonariuszami a Getin Holding podpisana została umowa sprzedaży akcji. Getin Holding kupił 99\% akcji Wschodniego Banku Cukrownictwa, za 210 mln z t $^{69}$. $\mathrm{W}$ ten sposób działalność zarządu komisarycznego we Wschodnim Banku Cukrownictwa została zwieńczona przejęciem banku przez Getin Bank.

\footnotetext{
${ }^{65} \mathrm{http}: / /$ miasta.gazeta.pl/bialystok/1,35234,2053077.html

${ }^{66} \mathrm{http}$ :/www.money.pl/banki/wiadomosci/artykul/bank;wschodni;dla;banku;spolem, 82,0,36178.html

${ }^{67}$ nie mylić z Eurobank EFG, greckim właścicielem Polbank SA

${ }^{68} \mathrm{http}: / /$ www.nbp.pl/aktualnosci/Wiadomosci 2002/knb 250602.html

${ }^{69} \mathrm{http}: / /$ prnews.pl/getin-bank/getin-bank-przejal-oddzialy-wschodniego-bankucukrownictwa-19179.html
} 
Ostatnim przykładem powołania w Polsce zarządu komisarycznego banku był przypadek Banku Przemysłowego SA. W banku tym KNB wprowadziła zarząd komisaryczny od dnia 18 marca 2003 roku $^{70}$. Po nieudanych negocjacjach z Kulczyk Holding SA i dalszych poszukiwaniach inwestorów ${ }^{71}$, Bank Przemysłowy SA został przejęty, dnia 13 grudnia 2004 roku, przez Getin Bank SA ${ }^{72}$. Znowu więc sanacja zakończyła się przejęciem banku.

\section{Zakończenie}

Instytucja zarządu komisarycznego jest środkiem postępowania naprawczego, który pochodząc spoza struktur banku oddziałuje na bank od wewnątrz. O ustanowieniu zarządu komisarycznego decyduje instytucja nadzorcza, samymi zaś członkami zarządu komisarycznego nie mogą być - ze względów słuszności - członkowie dotychczasowych organów banku. W związku z tym zarząd komisaryczny wkracza do banku jako ciało nowe, wręcz obce. Ponieważ jednak, zarząd komisaryczny wyposażony jest w kompetencje organów banku, oddziałuje on na bank od wewnątrz. Patrząc jednak na wyżej przytoczone dane dotyczące faktycznego funkcjonowania ustanowionych w bankach zarządów komisarycznych, nie sposób nie zauważyć, że ich działalność powadzi raczej do przejęcia banków, niż do uzdrowienia sensu stricto. Zapewne dlatego w literaturze przeważa pogląd, według którego instytucja zarządu komisarycznego nie jest do końca skuteczna ${ }^{73}$. Należy jednak pamiętać, że doprowadzenie do przejęcia banku stanowi poniekąd sukces postępowania sanacyjnego, bowiem skutki tego postępowania należy oceniać przede wszystkim z perspektywy klientów banku i bezpieczeństwa zgromadzonych przez nich środków na rachunkach bankowych.

\footnotetext{
${ }^{70}$ http://www.nbp.pl/Home.aspx?f=aktualnosci/Wiadomosci_2003/komunikat knb_180303.html

${ }^{71} \mathrm{http}$ ://www.bankier.pl/wiadomosc/GETIN-Bank-SA-przejmuje-Bank-Przemyslowy-w-Lodzi-1231994.html

${ }^{72} \mathrm{http} / /$ www.kpwig.gov.pl/Images/knb_101204_tcm20-9773.pdf

${ }^{73}$ T. Hoffmann, Zarzad komisaryczny na tle polskiej praktyki bankowej, Bank i kredyt, 1994 nr 9, s. 13; C. KosiKowski, Publiczne prawo bankowe, Warszawa 1999, s. 197.
} 


\section{Management of a Board of Receivers in Banking Law}

The appointment of a board of receivers is an instrument used in rehabilitation proceedings. The board of receivers originates from outside the bank but acts upon it from inside. The appointment of a board of receivers is an optional right of the Polish Financial Supervision Authority (Komisja Nadzoru Finansowego - KNF) and is applicable when the bank management board fails to submit a recovery program in accordance with art. 142(1) of the Banking Act or when the execution of that program is ineffective. The board of receivers is appointed by decision of the KNF. By virtue of art. 145(4) of the Banking Act, the KNF decision is administrative and, as such, can be appealed. The supervisory board of a bank subject to recovery measures may file an appeal to the Supreme Administrative Court within 7 days from the receipt of the decision. On the day the board of receivers is appointed all current governing authorities of the bank are suspended and replaced by the board of receivers, which takes over all their powers. This is why the board of receivers is often called "special bank authority". Main tasks of the board of receivers consist in drawing up a rehabilitation program and agreeing it with the KNF, administering the execution of the program, and reporting the results achieved under the program to the KNF and the supervisory board at intervals of no less than three months. 